\title{
SIKAP ANGGOTA SPa MEDICA \\ YOGYAKARTA TERHADAP SENAM \\ PENYEMBUHAN MEDICA \\ DALAM MENGATASI STRES
}

Oleh: Sigit Nugroho

Dosen Jurusan Pendidikan Kesehatan dan Rekreasi FIK UNY

\section{Abstrak}

Penelitian ini bertujuan untuk mengetahui sikap para anggota SPa Medica terhadap senam penyembuhan medica dalam mengatasi stres, dengan mengidentifikasi komponen sikap, kognitif, afektif, dan konatif. Hal itu mencakup sikap terhadap SPa Medica dan kesehatan, meditasi dan daya pikir, stres mental dan stres fisik para anggota SPa Medica Yogyakarta.

Populasi penelitian ini meliputi seluruh anggota di lima sanggar SPa Medica Yogyakarta. Pengambilan sampel dengan teknik insidetal sampling. Instrumen penelitian berupa angket dengan empat alternatif jawaban. Analisis data menggunakan teknik analisis data deskriptif.

Hasil penelitian menunjukkan bahwa anggota SPa Medica terhadap senam penyembuhan medica dalam mengatasi stres dalam kategori sangat positif dengan persentase untuk komponen kognitif $83.41 \%$, afektif $82.89 \%$, dan konatif $81.77 \%$. Di tinjau dari objek sikap, hasil perhitungan menunjukkan bahwa sikap anggota terhadap SPa Medica dan kesehatan $84.81 \%$, meditasi dan daya pikir $83.02 \%$, sedangkan untuk stres mental dan stres fisik $80.67 \%$. Dengan demikian dapat dikatakan bahwa secara umum anggota SPa Medica mempunyai pengetahuan, pandangan,

MEDIKORA Vol. II, No. 1, April 2006: 80 - 92. 
dan keyakinan yang sangat positif terhadap senam penyembuhan medica dalam mengatasi stres.

Kata kunci: komponen sikap, senam penyembuhan medica.

Stres adalah tekanan psikologis yang dapat menimbulkan penyakit fisik maupun penyakit jiwa. Hal-hal yang menimbulkan stres bagi seseorang belum tentu akan menimbulkan hal yang sama bagi orang lain. Upaya mengembangkan kehidupan yang bermakna dan memuaskan tidaklah mudah dalam era perubahan sosial dan teknologi yang sangat cepat ini. Suatu saat manusia merasa tidak mampu dan kadang-kadang sampai merasa putus asa. Kondisi ini dapat menimbulkan fenomena yang sering disebut dengan istilah stres yang dapat mengganggu kondisi fisik dan psikologis seseorang. Secara fisik akan menimbulkan gangguan pada sistem tubuh dan secara psikologis seseorang dapat mengalami kecemasan, waswas, rasa takut, dan sebagainya.

Penelitian SPa Medica (senam penyembuhan medica) ini akan mengetengahkan problem tersebut dan merumuskan suatu program untuk membantu mereka dalam menghadapi dan menanggulangi ketegangan atau stres. Program tersebut menunjukkan bagaimana menggunakan inisiatif dan sumbersumber dari diri sendiri, tidak hanya untuk membebaskan dari stres tetapi juga untuk memperbaiki cara hidup untuk mencapai keadaan yang baik. Dengan demikian, seseorang akan memperoleh kembali vitalitas dan perasaan sejahtera.

Berpikir secara konstruktif dalam banyak kasus akan bisa mengurangi atau menghindarkan stres. Di samping itu, seseorang akan mengetahui bahwa kunci kesehatan terletak dalam suatu program yang seimbang antara latihan mental, kegiatan fisik yang teratur, makanan yang baik, dan istirahat yang cukup (Grete Waitz, 1984: 1).

Teknik latihan SPa Medica berdasarkan kekuatan konsentrasi dengan memusatkan pikiran dan mengendalikan reaksi-reaksi terhadap keadaan yang penuh stres agar dapat terealisasikan dengan baik dan benar. Hasil teknik latihan $\mathrm{SPa}$ Medica yang diperoleh para anggota dipandang perlu untuk mengetahui seberapa jauh sikap anggota $\mathrm{SPa}$ Medica terhadap senam penyembuhan medica dalam mengatasi stres.

Sikap Anggota SPa Medica Yogyakarta Terhadap Senam ... (Sigit Nugroho) 
Berdasarkan uraian di atas, timbul dorongan penulis untuk mengetahui sikap anggota SPa Medica terhadap senam penyembuhan medica dalam mengatasi stres.

\section{KAJIAN PUSTAKA}

\section{SPa Medica (Senam Penyembuhan Medica)}

Menurut Wisnu Wardoyo (2003: 5-6) senam penyembuhan medica (SPa Medica) merupakan alternatif untuk memperoleh kesehatan yang diharapkan bisa mengefektifkan semua organ dalam tubuh secara optimal dengan olah napas dan olah fisik secara teratur, sehingga hasil metabolisme tubuh dan energi penggerak untuk melakukan aktivitas menjadi lebih besar dan berguna untuk menangkal penyakit.

Latihan/program SPa Medica dimaksudkan untuk menjaga kualitas berpikir yang sehat, agar mengalir energi positif untuk tujuan-tujuan yang baik. Menjaga ketenangan jiwa adalah menjadi dasar untuk memperoleh kondisi berpikir yang baik. Dalam keadaan pikir yang baik justru akan mengalir suasana cerah dalam diri orang bersangkutan dan otomatis telah menjaga proses penyegaran dalam diri orang tersebut. Secara fisik pun juga akan cepat terjadi proses pencerahan, pembaharuan sel-sel yang telah mati diganti dengan sel-sel baru, sehingga orang tersebut akan terasa hidup dalam putaran ritme yang beraturan.

Menurut Doriel Hall (1999: 3-4) meditasi berarti melakukan sesuatu, maksud kegiatan ini adalah mencapai keadaan meditasi, yang merupakan suatu keadaan bukannya perbuatan keadaan itu menimbulkan penyembuhan, kejernihan, dan kedamaian di mana kebingungan serta kecemasan sebelumnya berada. Keadaan tersebut menolong untuk menghadapi tantangan-tantangan dalam kehidupan. Berniat teguh dan teratur dalam menjalankan teknik-teknik itu akan membawa banyak manfaat, sepanjang seseorang memusatkan perhatian pada apa yang diharapkan akan tercapai.

\section{Sikap}

Para ahli psikologi berpendapat bahwa sikap adalah suatu bentuk evaluasi atau reaksi perasaan. Sikap seseorang terhadap suatu objek adalah perasaan mendukung atau memihak (favorable) maupun perasaan tidak

MEDIKORA Vol. II, No. 1, April 2006: 80 - 92. 
mendukung atau tidak memihak (unfavorable) pada objek tertentu. Di sisi lain, kelompok pemikiran yang kedua tokoh terkenal di bidang psikologi sosial dan psikologi kepribadian, yang konsepsi mereka mengenai sikap merupakan semacam kesiapan untuk bereaksi terhadap suatu objek dengan cara-cara tertentu (Saifuddin Azwar, 1997: 4-5).

Bimo Walgito (1980: 52) mengemukakan bahwa sikap adalah keadaan dalam diri manusia dengan perasaan-perasaan tertentu di dalam menanggapi objek dan terbentuk atas dasar pengalaman-pengalaman.

Dari berbagai pendapat di atas dapat disimpulkan bahwa sikap adalah pendapat, keyakinan seseorang mengenai objek atau situasi yang relatif ajek dan disertai dengan perasaan tertentu serta memberi dasar kepada orang tersebut untuk membuat respons atau perilaku dalam cara tertentu yang dipilihnya.

Menurut Saifuddin Azwar (1997: 23) struktur sikap terdiri atas tiga komponen, yaitu komponen kognitif (cognitive), komponen afektif (affective), dan komponen konatif (conative). Komponen kognitif merupakan respresentasi apa yang dipercayai oleh individu pemilik sikap yang berisi kepercayaan seseorang mengenai apa yang berlaku atau apa yang benar bagi objek sikap. Komponen afektif merupakan perasaan yang menyangkut aspek emosional, dan komponen konatif merupakan aspek kecenderungan berperilaku tertentu sesuai dengan sikap yang dimiliki oleh seseorang.

Dalam interaksi sosialnya, individu bereaksi membentuk pola sikap tertentu terhadap berbagai objek psikologis yang dihadapinya. Diantara berbagai faktor yang mempengaruhi pembentukan sikap adalah pengalaman pribadi, kebudayaan, orang lain yang dianggap penting, media massa, institusi atau lembaga pendidikan dan lembaga agama, dan faktor emosi dalam diri individu (Saifuddin Azwar, 1995: 30-36).

Nurdjannah dan Agus Dharma (1983: 102) menyatakan bahwa pengaruh stres secara fisiologis menyebabkan kerja sistem urat saraf yang otomatik yang menyiapkan untuk keadaan darurat diperpanjang, hal tersebut dapat menjurus ke arah kekacauan fisik seperti bisul, tekanan darah tinggi, dan serangan jantung. Stres yang gawat berlangsung melalui sistem urat saraf pusat untuk mengubah keseimbangan hormon, dapat juga merusak respons daya tahan seseorang. 
Menurut Taylor yang dikutip Bart Smet (1994: 141) menggambarkan beberapa jalan untuk menjelaskan bagaimana stres dapat mempengaruhi kesehatan.

a. The direct route. Stres dapat menghasilkan perubahan fisiologis dan psikologis yang mengakibatkan berkembangnya suatu penyakit.

b. The personality route (predisposisi). Kepribadian mempengaruhi individu untuk mengalami stres, yang kemudian akan mempengaruhi kesehatan.

c. The interactive route. Pendekatan ini menekankan pentingnya ketidak kebalan yang ada sebelumnya baik psikologis maupun fisik dalam hubungan stres dan kesehatan. Model ini menyatakan bahwa stres dapat mengarah kepada kesehatan.

d. The health behavior route. Stres dapat secara tidak langsung mempengaruhi kesehatan dengan cara mengubah pola perilaku individu.

e. The illness behavior route. Stres dapat secara langsung mempengaruhi perilaku kesehatan tanpa menyebabkan penyakit. Orang yang sedang stres menunjukkan perilaku kesehatan, yang dapat membawa pada keuntungan sekunder.

Menurut Albert M. Hutapea (1994: 89) penyebab terjadinya stres atau stresor secara umum, yaitu:

a. Tingkat dampak stres akan sangat ditentukan oleh sikap tiap-tiap individu. Contoh, gempa bumi yang dahsyat memang akan mengganggu setiap orang, akan tetapi kata-kata hinaan belum tentu akan mengganggu perasaan setiap orang yang menerimanya.

b. Keadaan lingkungan. Contoh, suara ribut yang berasal dari ruang kantor sendiri akan lebih dapat ditoleransi daripada yang berasal dari ruang kantor orang lain.

c. Hal yang diharapkan sebelumnya akan kurang mengganggu daripada hal yang kedatangannya sama sekali tidak diharapkan, dan dampaknya akan lebih besar jika kejadian itu tidak dapat diramalkan sama sekali.

d. Ketidakmampuan seseorang dalam mengatasi keadaan akan menimbulkan stres yang sangat besar. Seseorang akan lebih tenang dalam menghadapi masalah jika ia tahu bahwa dia akan mampu mengatasi masalah tersebut.

Menurut Grete Waitz (1984: 41-71) gejala-gejala stres dapat dibagi menjadi dua macam, yaitu: gejala mental dan gejala fisik. Contoh gejala

MEDIKORA Vol. II, No. 1, April 2006: 80 - 92. 
mental, di antaranya kegugupan dan kecemasan, iritabilitas/mudah terganggu, kegelisahan, dan fobia. Contoh gejala fisik, misalnya problema jantung, tekanan darah tinggi, ketegangan, sakit kepala, gangguan pencernaan, susah tidur, kesulitan menstruasi (haid), dan impotensi seksual.

Senam SPa Medica metode aktif untuk mencapai kondisi rileks. Senam $\mathrm{SPa}$ medica akan memperkuat tubuh dalam menghadapi stres dengan memperkuat sistem kardiovaskuler serta membentuk sikap positif. Senam penyembuhan medica juga dapat menggantikan letih mental dengan letih fisik, serta dapat berfungsi sebagai sarana pengenduran otot-otot yang menjadi tegang karena stres selama jam kerja.

Di dalam SPa Medica cara untuk mengatasi stres, yaitu dengan membiasakan diri untuk berpikir positif, tindakan untuk selalu merefleksikan diri, bermeditasi atau sekedar mendapatkan ketenangan, merupakan tindakan untuk mendapatkan kekuatan kembali dalam mengatasi kesulitan-kesulitan yang timbul yang dapat diakibatkan kegelisahan dalam diri untuk memperoleh suatu keinginan untuk terbebasnya dari suatu permasalahan hidup.

\section{METODE PENELITIAN}

Penelitian ini menggunakan metode survai dengan angket. Adapun populasi dalam penelitian ini adalah anggota Sanggar Senam Penyembuhan Medica di Daerah Istimewa Yogyakarta. Pengambilan data menggunakan teknik insidental sampel dan penentuan semua sampling tersebut hanya secara kebetulan saja dan tidak direncanakan.

Instrumen pada penelitian ini menggunakan angket berupa pertanyaan tertulis yang bertujuan untuk menggali informasi mengenai hal-hal yang diketahui dan yang dilakukan oleh responden tentang sikap anggota SPa Medica terhadap senam penyembuhan medica dalam mengatasi stres. Skor yang digunakan dalam penelitian ini adalah berdasarkan Skala Likert. Pemberian skor tiap-tiap jawaban disajikan dalam tabel sebagai berikut: 
Tabel 1. Pemberian Skor Jawaban

\begin{tabular}{|c|c|c|c|c|}
\hline \multirow{2}{*}{ Pernyataan } & \multicolumn{4}{|c|}{ Alternatif Pilihan } \\
\cline { 2 - 5 } & SS & S & TS & STS \\
\hline Positif & 4 & 3 & 2 & 1 \\
\hline Negatif & 1 & 2 & 3 & 4 \\
\hline
\end{tabular}

Keterangan:

SS = Sangat Setuju

$\mathrm{S} \quad=$ Setuju

TS = Tidak Setuju

STS = Sangat Tidak Setuju

Jumlah pernyataan dalam penelitian ini adalah 45 butir yang terbagi dalam tiga objek sikap dan tiga komponen sikap, yaitu: sikap anggota $\mathrm{SPa}$ Medica terhadap senam penyembuhan medica dan kesehatan 15 butir, sikap anggota SPa Medica terhadap meditasi dan daya pikir 15 butir, sikap anggota SPa Medica terhadap stres mental dan stres fisik 15 butir. Butir-butir pernyataan yang termasuk dalam setiap komponen sikap adalah komponen kognitif 15 butir, komponen afektif 15 butir, komponen konatif 15 butir. Untuk mengetahui kesahihan dan keterandalan butir pernyataan yang terdapat dalam instrumen dilakukan melalui butir tes.

\section{UJI VALIDITAS INSTRUMEN}

Pengujian validitas instrumen dalam penelitian ini dengan menggunakan bantuan komputer seri program stastistik (SPS) 2000 edisi Sutrisno Hadi dan Yuni Pamardiningsih. Berdasarkan hasil analisis komputer ternyata untuk butir pernyataan komponen kognitif dari 15 butir tidak ada yang gugur. Sedangkan untuk komponen Afektif dari 15 butir terdapat 7 butir yang gugur dan untuk komponen konatif dari 15 butir terdapat 3 butir yang gugur. Dengan demikian secara keseluruhan dari 45 butir terdapat 10 butir yang gugur sehingga jumlah butir yang valid menjadi 35 butir.

MEDIKORA Vol. II, No. 1, April 2006: 80 - 92. 


\section{UJI RELIABELITAS INSTRUMEN}

Pengujian reliabelitas instrumen dalam penelitian ini dengan mengunakan rumus Alpha Cronbach. Adapun hasil Uji Reliabilitas dalam penelitian ini adalah reliabelitas instrumen variabel sikap anggota $\mathrm{SPa}$ Medica Yogyakarta terhadap senam penyembuhan medica dalam mengatasi stres sebesar 0.957 . Oleh karena $\mathrm{rtt}=0.957$ dan peluang (p) kesalahan adalah 0.000 maka dapat disimpulkan bahwa instrumen penelitian ini adalah reliabel.

Setelah semua data terkumpul, selanjutnya menganalisis data sehingga data tersebut dapat ditarik suatu kesimpulan, kemudian data dimasukkan untuk dikelompokkan sesuai dengan hasil angket. Teknik analisis data yang dipergunakan dalam penelitian ini adalah analisis deskriptif kuantitatif dengan persentase, data yang diperoleh bersifat kuantitatif berupa angka-angka. Hasil perhitungan yang diperoleh dijumlahkan dan hasilnya dibandingkan dengan jumlah skor yang diharapkan sehingga diperoleh persentase.

Skor keseluruhan

Skor yang diharapkan

$$
\text { X } 100 \%
$$

Hasilnya dimasukkan dengan standar nilai yang dipakai untuk memberi arti hasil hitungan melalui persentase. Menurut Suharsimi Arikunto (1998: 246) standar nilai yang dipakai sebagai berikut:

$76-100 \%$ termasuk kategori sangat positif

$56-75 \%$ termasuk kategori positif

$40-55 \%$ termasuk tidak positif

Kurang dari $40 \%$ termasuk sangat tidak positif

\section{HASIL PENELITIAN}

Penyebaran angket di empat sanggar SPa Medica yang masih aktif latihan, yaitu sanggar SPa Medica perumahan Sedayu, Griya Kencana Permai, Gedong Kiwo, dan sanggar SPa Medica UNY. Data yang terkumpul sebanyak 40 responden. Deskripsi hasil penelitian yang dilakukan dengan perhitungan secara manual dapat dilihat seperti di bawah ini : 
Tabel 2. Data Penelitian

\begin{tabular}{|c|c|c|c|c|}
\hline \multirow{2}{*}{$\begin{array}{l}\text { Komponen } \\
\text { Sikap }\end{array}$} & \multicolumn{3}{|c|}{ Kompopnen Objek Sikap } & \multirow[b]{2}{*}{ Total } \\
\hline & $\begin{array}{l}\text { SPa Medica } \\
\text { dan } \\
\text { Kesehatan }\end{array}$ & $\begin{array}{c}\text { Meditasi } \\
\text { dan } \\
\text { Daya piki }\end{array}$ & $\begin{array}{c}\text { Stres fisik } \\
\text { dan Stres } \\
\text { Mental }\end{array}$ & \\
\hline Kognitif & 675 & 672 & 655 & 2002 \\
\hline Afektif & 275 & 396 & 390 & 1061 \\
\hline Konatif & 407 & 659 & 504 & 1570 \\
\hline Jumlah & 1357 & 1727 & 1549 & 4633 \\
\hline
\end{tabular}

1. Hasil Perhitungan dan Persentase Sikap Anggota

Skor keseluruhan sikap anggota $=4633$ skor yang diharapkan sikap anggota adalah $35 \times 4 \times 40=5600$.

Perhitungannya sebagai berikut:

$$
\mathrm{P}=\frac{4633}{5600} \times 100 \%=82.73 \%
$$

Dengan demikian apabila hasil perhitungan tersebut diklasifikasikan termasuk dalam kategori sangat positif, artinya bahwa senam penyembuhan medica sangat baik untuk mengatasi stres.

2. Hasil Perhitungan dan Persentase Komponen Sikap

a. Hasil Perhitungan Komponen Kognitif

Skor keseluruhan komponen kognitif $=2002$

Skor yang diharapkan komponen kognitif adalah $15 x 4$ x $40=2400$

Perhitungannya sebagai berikut:

$$
\mathrm{P}=\frac{2002}{2400} \quad \text { X } 100 \%=83.41 \% \text {. }
$$

MEDIKORA Vol. II, No. 1, April 2006: 80 - 92. 
Dengan demikian klasifikasinya termasuk dalam kategori Sangat Positif. Dari hasil perhitungan tersebut berarti aggota SPa Medica Yogyakarta mempunyai pengetahuan, pandangan dan keyakinan yang sangat positif terhadap senam penyembuhan medica yang diberikan oleh Instruktur.

b. Hasil Perhitungan Komponen Afektif

Skor keseluruhan komponen afektif $=1061$, skor yang diharapkan komponen afektif $8 \times 4 \times 40=1280$.

Perhitungannya sebagai berikut:

$\mathrm{P}=\frac{1061}{1280} \times 100 \%=82.89 \%$.

Dengan demikian klasifikasinya termasuk dalam kategori sangat positif. Dari hasil perhitungan tersebut berarti aggota SPa Medica Yogyakarta mempunyai rasa senang atau sikap sangat positif terhadap senam penyembuhan medica dalam mengatasi stres.

c. Hasil Perhitungan Komponen Konatif

Skor keseluruhan komponen konatif $=1570$, Skor yang diharapkan komponen konatif adalah 12x4 x $40=1920$.

Perhitungannya sebagai berikut:

$$
\mathrm{P}=\frac{1570}{1920} \quad \mathrm{X} 100 \%=81.77 \% \text {. }
$$

Dengan demikian klasifikasinya termasuk dalam kategori sangat positif. Dari hasil perhitungan tersebut berarti Aggota SPa Medica Yogyakarta selalu bertindak sangat positif terhadap senam penyembuhan Medica dalam mengatasi stres.

3. Hasil Perhitungan dan Persentase Objek Sikap

a. Sikap anggota SPa Medica terhadap SPa Medica dan Kesehatan

Skor keseluruhan objek sikap SPa Medica dan kesehatan anggota $=1357$, skor yang diharapkan objek sikap SPa Medica dan kesehatan adalah 10x4 $\mathrm{x} 40=1600$. 
Perhitungannya sebagai berikut:

$$
P=\frac{1357}{1600} \times 100 \%=84.81 \% \text {. }
$$

Dengan demikian klasifikasinya termasuk dalam kategori sangat positif. Berarti bahwa senam penyembuhan medica dengan SPa Medica dan Kesehatan dapat mengatasi stres, terbukti dengan apa yang telah dirasakan oleh para anggota di sanggar-sanggar SPa Medica yang ada di Yogyakarta.

b. Sikap aggota SPa Medica terhadap meditasi dan Daya Pikir

Skor keseluruhan objek sikap meditasi dan daya pikir $=1727$, skor yang diharapkan objek sikap meditasi dan daya pikir adalah $13 \times 4 \times 40=$ 2080.

Perhitungannya sebagai berikut:

$$
\mathrm{P}=\frac{1727}{2080} \times 100 \%=83.02 \% \text {. }
$$

Dengan demikian klasifikasinya termasuk dalam kategori sangat positif. Berarti bahwa senam penyembuhan medica dalam mengatasi stres harus disertai meditasi dan daya pikir, terbukti dengan apa yang telah dirasakan oleh para anggota di sanggar-sanggar $\mathrm{SPa}$ Medica yang ada di Yogyakarta.

c. Sikap anggota SPa Medica terhadap Stres Mental dan Stres Fisik Skor keseluruhan objek sikap stres mental dan stres fisik $=1549$, skor yang diharapkan objek sikap stres mental dan stres fisik adalah $12 \mathrm{x} 4 \mathrm{x}$ $40=1920$.

Perhitungannya sebagai berikut:

$$
\mathrm{P}=\frac{1549}{1920} \times 100 \%=80.67 \% \text {. }
$$


Dengan demikian klasifikasinya termasuk dalam kategori sangat positif. Berarti bahwa senam penyembuhan medica dapat mengatasi stres baik fisik maupun mental, terbukti dengan apa yang telah dirasakan oleh para anggota di sanggar-sanggar SPa Medica yang ada di Yogyakarta.

\section{PEMBAHASAN}

Hasil penelitian seperti tersaji di atas memberikan gambaran bahwa secara keseluruhan sikap anggota SPa Medica terhadap senam penyembuhan medica dalam meng tres termasuk dalam kategori sangat positif. Hal ini menggambarkan bahwa senam penyembuhan dalam mengatasi stres yang diberikan oleh para pengajar SPa Medica disikapi secara positif oleh para anggota SPa Medica. Sikap ini disebabkan oleh jasa para penggajar yang diberikan di sanggar-sanggar sesuai dengan harapan anggota SPa Medica.

Dengan demikian semua anggota SPa Medica yang ada di Yogyakarta menyatakan bahwa latihan senam penyembuhan medica dapat mengatasi dan mengurangi risiko terkena stres.

\section{KESIMPULAN}

Berdasarkan hasil penelitian dapat disimpulkan bahwa anggota SPa Medica Yogyakarta bersikap sangat positif terhadap senam penyembuhan medica dalam mengatasi stres. Ditinjau dari komponen sikap, komponen kognitif, komponen afektif, dan komponen konatif hasilnya termasuk dalam kategori sangat positif. Ini berarti anggota SPa Medica Yogyakarta mempunyai pengetahuan yang sangat positif dan merasa senang terhadap senam penyembuhan medica dalam mengatasi stres.

Dilihat dari objek sikap SPa Medica dan kesehatan, meditasi dan daya pikir, stres mental dan stres fisik juga termasuk dalam kategori sangat positif. Ini berarti anggota SPa Medica Yogyakarta sangat mendukung bahwa SPa Medica dan kesehatan, meditasi dan daya pikir, di dalam senam penyembuhan medica dapat mengatasi stres mental dan stres fisik. Berdasarkan hasil tersebut di atas disarankan kepada para anggota SPa Medica untuk mengurangi risiko terkena stres agar tetap menjaga kondisi tubuh dan sering latihan walaupun tidak sesuai dengan jadwal latihan. Hal ini disebabkan oleh risiko terkena stres bisa muncul 
setiap saat. Oleh sebab itu, seseorang harus selalu memikirkan hal-hal yang positif agar mengalir suasana cerah sehingga terjaga proses penyegaran tubuh.

\section{DAFTAR PUSTAKA}

Albert M. Hutapea. (1994). Menuju Gaya Hidup Sehat: Kiat Praktis untuk Setiap Orang Sibuk yang Ingin Sehat dan Fit. Jakarta: Gramedia Pustaka Utama.

Bart Smet. (1994). Psikologi Kesehatan. Jakarta: Gramedia Widiasarana Indonesia.

Bimo Walgito. (1980). Psikologi Sosial. Yogyakarta: Yayasan Penerbit Fakultas Psikologi UGM.

Doriel Hall. (1999). Penyembuhan dengan Meditasi. Jakarta: PT Gramedia Pustaka Utama.

Grete Waitz, Sigmund S., \& Willi S. (1984). Mengatasi Ketegangan Bersama Grete Waitz. Bandung: Angkasa.

Nurdjannah Taufiq dan Agus Dharma. (1983). Pengantar Psikologi. Jakarta: Erlangga.

Saifuddin Azwar. (1997). Reliabelitas dan Validitas. Yogyakarta: Pustaka Pelajar (Anggota IKAPI).

Suharsimi Arikunto. (1998). Prosedur Penelitian Suatu Pendekatan Praktek (Edisi Revisi IV). Jakarta: PT Rineka Cipta.

Wisnu Wardoyo. (2003). Revitalisasi Senam Penyembuhan Medica. Yogyakarta: SPa Medica

MEDIKORA Vol. II, No. 1, April 2006: 80 - 92. 